\title{
GARY MARKER
}

\section{RUSSIA'S EIGHTEENTH CENTURY IN RECENT US HISTORIOGRAPHY ${ }^{1}$}

Eighteenth-century Russian studies in the US has witnessed a number of notable shifts over the past two decades, including a movement away from grand narratives and overdetermined teleologies, the emergence of new areas of concentration, new approaches to old questions, and-most significantly-the collapse of the Russia/West antinome in historiography. This article highlights five vectors in which some of the most original work is currently taking place: the multiplicity of blurred boundaries; the place and practices of religions and confessions (Russian Orthodox as well as others); empire as multi-peopled and as state formation; structures of society and lived experiences; and gender. Within each of them the field has seen a resurgence of source-based empirical research, as well as skepticism toward received wisdoms. There has also been a desire to look beyond the metropole and centers of power and to concentrate on experiences far removed from St. Petersburg and Moscow, sometimes in the form of micro-studies, other times in the form of regional or non-Russian outlooks. The essay offers a brief discussion of each of these vectors, identifies some of the most noteworthy scholarship in each, and concludes with some suggestions regarding where the field might go next.

Keywords: Russia, eighteenth century, US, religion, empire, gender, structures of society, blurred boundaries

Gary Marker (PhD) - Professor Emeritus of History at Stony Brook University, Stony Brook, New York, USA. E-mail: Gary.Marker@Stonybrook.edu

1 Citation: GARY MARKER, "Russia's Eighteenth Century in Recent US Historiography", RussianStudiesHu 4, no. 1 (2022): 25 pp. DOI: 10.38210/RUSTUDH.2022.4.1 


\section{INTRODUCTION}

These days, Russia occupies a far smaller space within American academia than it did during the decades of the Cold War. If one goes simply by the numbers of PhDs and new English-language publications from the past two decades, the study of Russian history has ebbed considerably from those towering heights. This diminution, and the inevitable shifts in interests that occur from one generation to the next have meant that our field today looks very different in virtually all respects from what it was previously. And what is true for the field overall is acutely so for the pre-modern periods. Formerly prominent areas of eighteenth-century research, including new social history, the service careers of nobility, foreign policy, legal institutions, intellectual history, economic history, serfdom, and peasant rebellions (whither Pugachevshchina?) still generate interest, but considerably less than in decades past.

If one looks beyond the metrics and the dimming of old standard bearers, however, to the research itself, the picture looks a good deal livelier. Dixuitiemisme remains a productive and innovative space of American Rusistica, and arguably more imaginative and multi-dimensional than in bygone times. Where once our research was shaped in large measure by a handful of core paradigms and "eternal questions" (antinomes of Russiaand-the-West, backwardness-and-civilization, the place of intelligentsia, etc.) current specialists have, with a few noteworthy exceptions, mostly dispensed with a priori paradigms. One finds a healthy skepticism toward nearly all received generalizations, and an inclination instead to return to the sources, especially little-used, previously unexplored, and provincial ones. Archival research-at least prior to COVID-19-has flourished. Openness to new or little explored questions has become commonplace; research on life in the provinces and on non-Russian peoples occupies a place of prominence, as do micro-historical life experiences, gender, religion, and many other sites of research.

One thing that has not changed is the sub-field's long tradition of interdisciplinarity. If anything, it is now more extensive than before, with the recent incorporation of visual texts (see for example, Levitt, 2011; Kivelson and Neuberger, 2008), spacialization (O'Neill 2018; Randolph, 2007, 2010, 2016, et al.) and digital humanities (e.g., Hoogenboom, 2014) into Clio's realm, a capacious space that has for generations welcomed literary studies and the social sciences. It remains the case that one is 
often hard pressed to determine from the expositions where the writing of history ends, and these other disciplines begin. Good! And just to be clear, contraction notwithstanding, the past two decades have produced many more noteworthy contributions addressing far too many subjects than can be accommodated in a short review such as this. Rather than attempt comprehensive coverage, therefore, this essay will limit itself to a limited set of categories, within which important new lines of research have emerged, as well as new perspectives on the questions historians explore and the ways they organize their narratives: 1) Blurred Boundaries 2) Religion; 3) Empire, State and Rulership; 4) Structures of Society and Lived Experience; 5) Gender. A complete check list of relevant publications runs into the dozens, and those mentioned here constitute nothing more than a representative selection of important work on current trends and themes.

\section{BLURRED BOUNDARIES}

In an earlier essay for this series, Charles Halperin began his comments with the salient observation, that "There is no 'US School' of Muscovite history", by which he meant that US historians, like scholars everywhere, disagree among one another about pretty much everything. That, of course, is exactly how it should be, since so-called national schools of thought more often than not have seasoned serious research with a heavy dose of ideology, political agendas, and закономерности not infrequently superimposed or naturalized from beyond academia. In fact, though, the challenges that scholars currently confront when attempting to delineate boundaries of national historiographies in the global milieu of twentyfirst century scholarship run much deeper. There are also questions about disciplinary boundaries, some of which are rather specific to eighteenthcentury studies, but for those our field has long embraced a generous and welcoming approach, perhaps in homage to the Enlightenment.

\section{Blurred Boundaries 1: Knowledge, Nations, and Space.}

Notwithstanding the ferocious and ongoing contestations worldwide over the meanings and consequences of globalization, including the so-called knowledge economy-their characteristics, sources, and consequences, whether they constitute positive modes of integration or a corrosive loss of national identity and sovereignty, etc.-I would argue that within 
academia, and in particular within Russian historical studies, the impact of globality on the production of new knowledge has been largely a story of success and of major strides forward in transnational collaborations. The end of the Cold War brought about the demise of the competing liberal and Soviet Marxist master narratives of history, their respective teleologies of progress, and ultimately, I dare say, the twilight of the very notion of history as progress (of course, other determinisms-ethnic, national civilizational, spatial-have flowed into the void, but thankfully so far they have played a minor role in eighteenth-century scholarship). Add to that the profound impact of both digital communications and global mobility on scholarly activity and we see the fall of one boundary after another. Numerous scholars educated in Russia or other countries currently work in the United States; a somewhat smaller number of US Russianists work abroad. Academic conferences and symposia routinely include participants from throughout our professional communities.

\section{Blurred Boundaries 2: Common Discourses.}

Far more than had been true for Cold-War era scholars, the current generation tends to read and be inspired by the same body of works, speak to one another as individuals-and disagree with one another as individuals-about emergent scholarship and bodies of thinking with which we are all familiar. We collaborate in our journals, collective projects, online groups, etc., in ways that regularly ignore geographic markers. Throughout the process of initiating new hypotheses and bodies of research, specialists in this field generally interact without reference to national schools or boundaries. In other words, almost anything that can be said about contemporary American historiography of Russia applies as well to the historiography in any country in which eighteenth-century Russia still thrives in the academy. So, if the production of historical knowledge has become so blended geographically, we need ask, what constitutes American scholarship? The answer, frankly, is geography pure and simple: scholars who currently work primarily within US academia, irrespective of the language(s) in which they publish and their national origin, as well as US scholars currently working elsewhere, are included. 


\section{Blurred Boundaries 3: Periodization and Time.}

'Древняя Русь' /'Имперская/Современная Россия'. If you are reading this essay, you most assuredly are familiar with these hallowed (i.e., old) categories, the standard topoi which generations of scholars employed to differentiate everything that came before Peter from everything that followed. But did anyone ever understand what they signified and where the eighteenth century fits into this crude two-phase chronology?

Today's historians, though, both in Russia and elsewhere, have largely drifted away from these terms, frequently employing the familiar European language of 'early modern' for example to denote roughly the time from Ivan IV through the eighteenth century. For some (but by no means all) of those who have engaged in the discussion, this shift towards the term 'early modern' constituted an explicit rethinking of long-held assumptions about a Petrine divide, and more generally about periodization and loci of epochal shift. Ever more Muscovite historians are pushing the end dates of their projects deep into the eighteenth century. Some eighteenth-century studies likewise now begin their narratives decades or even centuries before Peter. This lively interrogation of epochs has been the focus of essays by Ernest Zitser (Zitser 2005; 2016) and a few others. In 2010, for example, Slavic Review devoted a forum, entitled "Divides and Ends: Periodizing the Early Modern in Russian History," that confronted the issue directly. One of the contributors, Donald Ostrowski, maintained that the basic institutions of empire and patterns of development and expansion were in place well before Peter, and only slightly modified by his reforms. For Ostrowski, eighteenth-century Russia belongs firmly within Muscovy, a period that ends only around 1800 (Ostrowski, 2010; see also Russell Martin's and Nancy Kollmann's comments in this forum).

Here then is the gauntlet: can we speak of a 'Petrine revolution', a moment of discontinuity and transformation that gave specific shape to the eighteenth century? Ostrowski's answer is a decisive 'no.' Others, most prominently James Cracraft, strongly disagree. In three major studies of the Petrine era, on architecture (Cracraft, 1988), imagery (Cracraft, 1997), and Russian culture (Cracraft, 2004) respectively, as well as some shorter works, Cracraft makes a robust defense of the established idea of a 'Petrine revolution.' He agrees with those authors of earlier generations who saw Peter's reign as a profound rupture in Russian history, a disruption that led to the victory in the Northern War, the creation of a new capital, and in their wake the Empire. But in his view the whole of that revolution was 
much greater than the sum of its parts. He encapsulates the argument this way: "What happened of greatest historical significance...was not the achievement for Russia of great power status. Nor was it Peter's modernization... Rather it was all of these and something more. That something, I argue, was a cultural revolution." (Cracraft, 2003, p.vii.). Most eighteenth-century specialists (here I would include myself) accept Cracraft's basic point, albeit in more muted terms, even as they opt for "early modern" and eschew "revolution," that Peter ushered in important and epoch-making changes, in Zitser's words, "the difference that Peter I made" (Zitser, 2016).

Another way in which periodization is being reimagined has less to do with the Petrine episteme per se and more to do with empire: what constituted it and when should we date its onset? Did it begin, as several scholars currently argue, with the conquest of Kazan in 1552? Or, as the more traditional view has it, did it come into existence only with the formal declaration of a Russian Empire in 1721? Two decades ago, Seymour Becker posed this question explicitly (Becker, 2000), and since then the field of Russian empire studies has taken off, and it is worth noting that all these new books begin their accounts well before Peter, as part of their separate interrogations of the big questions of what empire meant, when, and to whom. We shall return to the study of empire in a subsequent section, but for the moment it is important to keep in mind the inextricable link connecting periodization and typology, i.e., how one defines empire largely determines when it began. This is an ongoing and important debate in the literature, one for which a consensus is nowhere in sight.

\section{RELIGION}

The past two decades have seen a stunning surge in writing religion into the central narratives of modern Russian history, more so than at any time in memory. In its current iteration scholarship on religion has been broadly conceived: the place of faiths, rituals, and confessions, the interactions between clergy and laity, the institutional evolutions of Orthodoxy, church and state, theologies, sectarianism, Old Believers, etc.- and Englishlanguage scholarship is no exception. Although quite distinct in subject matter these works tend to intersect at key interpretive questions: the place of religion, and Orthodoxy in particular, in Russian letters; the penetration-or lack of same-of western Christian outlooks within Russian 
clergy; the place of the church, and religiosity in general, in state, ideology, and society; doctrinal and personal conflicts within the church; and sermons and the evolution of homiletic practices in the eighteenth century.

Although all of the Empire's major religions have received attention, most works not surprisingly have dealt with Russian Orthodoxy, the Patriarchate and Synod, the sharp decline of monasteries and monastic lands, and the interconnection between state and diocese. Here the legacy of Gregory Freeze's scholarship deserves particular mention, especially his 1980 book, The Russian Levites. One striking shift in the scholarship has been what might be termed a re-sacralization of the historiography, i.e., returning the theological and spiritual core of Russian Orthodoxy to the center of attention, albeit with a continuing awareness of institutions and politics. If they examined sermons at all, previous historians looked primarily for what they said about rulers (almost always meaning Peter the Great and Catherine the Great), legitimacy, and the state. Current scholarship remains deeply interested in the political and dynastic aspects, but it recognizes that sermons were, first, orated primarily in sacred or consecrated spaces (usually cathedrals); second, penned by seminarytrained clergy; and third, defined by faith above all else. But here is where consensus comes to an end.

More than a few scholars have wondered what it all amounted to in the end, for example vis-à-vis Russia's participation in pan-European intellectual developments. Max Okenfuss' somewhat controversial 1995 study of eighteenth-century book culture deserves mention in this context for its insistence that, in marked contrast to the Ruthenian experience and that of western Christendom, Latin Humanism never took hold on Muscovite/Russian soil, in large part because, as he argued, few Russians could read or understand the classics in their original languages (Okenfuss, 1995). He found little sign of Greeks and Latins in Russia's libraries or reading practices, and he concluded that the wave of Humanism metaphorically crashed on Russia's shores without advancing ("the resilience of Muscovy," as he has termed it.)

Okenfuss' thesis has garnered attention, although less so among US historians than among scholars within Russia itself, some of whom have argued in response that the classics resonated much more widely in the eighteenth century than previously imagined. The issue, though, remains wide open. In the US, Nikolaos Chrissidis' detailed study of Petrine era seminary training in Novgorod and Moscow offers something of a counterpoint, though not a critique. (Chrissidis, 2016). Chrissidis' main 
subject is the work of the Greek Leichoudes (Лихуды in Russian) brothers in transposing a Latin-based Jesuit curriculum onto Muscovite soil, what Okenfuss in an earlier article termed "the Jesuit origins of Petrine education." (Okenfuss, 1973). Of course, the Kyiv Metropolia had initiated a very rigorous Latin-based version of Jesuit-based training decades earlier under Petro Mohyla as a response to the Counter Reformation in the Polish Commonwealth. When the Hetmanate was incorporated into Muscovy after the Treaty of Pereiaslavl the Ruthenian seminaries in a formal sense became part of Muscovy as well. But Chrissidis is surely correct in his situating the Leichoudes at the forefront in bringing it to Muscovy proper, from whose beginnings it spread to the entire seminary system after 1737.

Another strain of current scholarship (once again, actively pursued in several countries) has explored the presence not of Latin Humanism but rather of Protestant thinking, beyond the widely acknowledged place of Pietism on eighteenth-century clerical thinkers, and through them the influence of Protestant ideas, often unattributed, within lay educated society. Some of the most recent work, including a handful of dissertations, has taken this argument quite far indeed, and we will watch with interest to see how the conversation proceeds over the next several years. This is not a new topic, certainly, as anyone familiar with the raging polemic between philo-Catholics and philo-Protestants in the Petrine church, or with George Florovskii's insistence many decades ago that Feofan Prokopovich was for all practical purposes a Protestant, knows full well. A recent issue of the online journal Vivliofika (Vol. 5 2017), entitled "Protestantism in Russia During the Eighteenth and Early Nineteenth Centuries" was devoted entirely to the Protestant presence in Russian letters. Andrey Ivanov, one of the contributors to that issue, subsequently published a recent monograph (Ivanov, 2020) in which he argued that the Russian Orthodox church underwent a genuine "reformation" or "spiritual revolution" in the eighteenth century, a thesis that is likely to spark a good deal of discussion.

Related to this is the concept of an "Orthodox Enlightenment," beginning in mid-century and continuing through the reign of Catherine the Great, in which leading clergy effectively integrated Enlightenment ideas and categories, including those from Protestant Europe, into their writing. Several scholars have pointed out the engagement of educated hierarchs with Russia's educated society, salons, literary correspondence, participation in journals, etc. Following the lead of the late Viktor Markovich Zhivov, whose writings have had a considerable influence 
on US scholarship, some of the literature has emphasized the changing rhetorical tone of sermons, the shift away from Neo-Scholasticism to a simpler, more vernacular and everyday-life focused mode of preaching. Noteworthy here is a book by Elise Wirtschafter on Metropolitan Platon Levshin (Wirtschafter, 2013). Her close reading of Platon's sermons reveals an outlook she terms "moral Enlightenment", deeply infused with both Orthodox and secular Enlightenment thinking.

Along these lines Gary Hamburg's voluminous study of what he terms "Russia's long path towards Enlightenment," which in his account began in 1500, deserves a mention. (Hamburg, 2016) Through his many works on intellectual history, Hamburg has mastered an effective narrative style that employs lengthy exegeses so as to foreground the writings themselves, while simultaneously interspersing his own readings of the texts. Given the longue durée and trans-epochal structure of the book, this approach proves very effective. But it is not without a bit of controversy, specifically about the relative absence of religious thought in the postPetrine exegeses. Although not specifically a history of confessional writings, Hamburg does give religious thought a visible place, both in the subtitle ("Faith, Politics, and Reason") and in the narrative, especially in the lengthy sections on Muscovy. Unlike Wirtschafter, though, he does not explore the idea of an eighteenth-century Orthodox Enlightenment, and instead envisions Russia's Enlightenment as primarily lay and secular, with relatively little input from religious thinkers. A generation or two ago this unspoken transition might have gone unnoticed, but it is a sign of the changed perspectives in our field that today it has drawn attention, largely to pose the question squarely as a site for open discussion and debate: where and how should Russianists situate religious ideas and thinkers in eighteenth-century intellectual history. Let me say yet again, this is all to the good, an important upside of historiographic discourses in common ("Blurred Boundaries Number 2").

Over the past two decades Olga Tsapina has written several thoughtprovoking articles on a variety of the themes mentioned here, including liturgy, theology, church-state relations, secularity and faith, and the Old Believers (Tsapina, 2001, 2006, 2014, 2018). An abiding element of her work is to show that theological disputations within the educated clergy were ongoing and generally well-informed, and to demonstrate that spiritual issues engaged both clerical and lay figures throughout the century. Although Tsapina does not say so explicitly, the picture she draws is not unlike Wirtschafter's, i.e., that the discourses of faith and secularity were 
far less siloed than scholars once thought. In this she is slowly being joined by an ever-growing cohort of younger scholars. Among these intersections are recent studies on faith and esoterica in the reading and writing of clerical hierarchs. Robert Collis has taken the lead in this realm, authoring several close readings dealing with alchemy, astrology, and spirituality among Petrine era clergy and educated courtiers, most notably in his book The Petrine Instauration (Collis, 2011). What he finds is that Ruthenianeducated hierarchs often were well versed in alchemical and astrological literature, and some took it quite seriously (as did Peter himself). Ernest Zitser has collaborated with Collis on some of this work (Zitser and Collis, 2015), and he is currently pursuing a full-length study of Boris Kurakin, (Zitser, 2011) along much the same lines.

Oddly, one area that has received comparatively little attention in recent US scholarship is popular Orthodoxy, especially as practiced among the mass of Orthodox peasants. The contrast here with the current state of the historiography of Muscovy, in which research on popular worship, magic, witchcraft, sectarianism, etc. are flourishing, is striking. As the following two examples show, however, this relative shortfall may be in the process of changing.

Nadieszda Kizenko (Kizenko, 2019 and 2021) has published several articles and a recent book that present a searching and exhaustive analysis of the rituals of confession (говение) over the Imperial period. Kizenko's works examine the concrete practices-or non-practices-of confession at a given time and in specific parishes, dioceses and in the physical spaces of churches, set against the backdrop of theological reflection and the Synod's intrepid pursuit of standardization of records (the Confessional Registries [исповедные росписи] that churches were nominally required to maintain) and formalization of ritual throughout the Orthodox population. This approach allows her to contextualize a variety of subjects that lie at the intersection of social history and religion-gender, the self, social differentiation, etc., the blending of which is unusual in this field. Where, for example, did confessors stand? Was confession in some sense publicly visible? What did it consist of, and was it different for different social groups, for men and women, for countryside and city? Her overarching conclusion is that Russian Orthodox confessional practices were rather elastic over time and place, in ritual performance, content, and frequency.

Barbara Skinner's account of East Slavic Uniate-Orthodox relations during the eighteenth century (Skinner, 2009) also foregrounds religion as a primary site of on-the-ground contestation, albeit with a focus on 
large communities of believers rather than specific quotidian practices. She argues that relations between Uniate communities in Ukraine and Belarus, on one side, and the Imperial state on the other vacillated along a rather broad spectrum, ranging from intense conflict and repression to-periodically-modest accommodation and something approaching de facto toleration. This description is embedded in a still larger narrative that complicates regional alterities among East Slavic peoples (and sometimes between East Slavs and Western Slavs) by characterizing them as being as much confessional as they were ethnic, geographical, or national. She delineates these relations throughout the century, comparing the situation of Uniates in the Polish Commonwealth with the more fraught circumstances of those residing within the borders of first Muscovite and then and Imperial Russia.

As Skinner's book demonstrates, it is no longer feasible to separate the study of non-Orthodox confessional communities in Russia from its Imperial, and by extension multi-confessional, geopolitical setting. This is particularly true for Muslim populations, whose significant presence in Russian history began well before the eighteenth century vis-à-vis Tatars, the many Steppe peoples, Uzbek merchants in Siberia, etc. This imperative is made manifest in a spate of recent studies about non-Orthodox peoples (so-called иноверцы). Paul Werth has written a valuable overview of the subject for the entirety of the Imperial period, centered largely on the question of toleration and conversion. (Werth 2014). Most works, however, have concentrated on specific faiths and ethno-confessional communities. There has been a scattering of work on Catholicism, as well as Judaism and the Empire's Jewish subjects, a consequence of the partitions of Poland (1772-1795) through which the Russian state acquired a Jewish population of approximately 800,000 around whom it soon constructed the Pale of Settlement. (e.g., Petrovsky-Shtern, 2014). But it is Islam, the religion of millions of the Empire's subjects that has quite appropriately garnered the most attention.

Quite a few current scholars of Islam in Russia give the eighteenth century a prominent place as a time of importance both within those communities and in their connections with the Russian state [more on this in the section on empire]. While they disagree-sometimes quite sharplyamong themselves about some very fundamental questions (which sources to use, which languages are sine-qua-non, the centrality of Russia in the thinking of its Muslim elites, center vs. periphery, the politics of conversion, cross-confessional cooperation, etc.), each of them contextualizes their 
work around critical vectors and structures: empire, local and regional institutions especially on the Volga and to its southeast, and most notably trans-imperial relations, a function of the active cross-border connections between Russian Muslim communities and those in the Ottoman Empire, Persia, and Afghanistan.

\section{EMPIRE, STATE AND RULERSHIP}

The fact of Empire is universally recognized in Russian studies, but in addition to the matter of periodization discussed earlier, questions regarding its structure, meaning, and peripheries have significantly reshaped the scholarship over the last twenty years, not just in the US but in the now flourishing field of empire studies more widely. Much of this work has been embedded in long histories of the Russian Empire: Valerie Kivelson and Ron Suny (2016), Nancy Kollmann (2016), Alfred Rieber (2014), and John LeDonne (2020), [here it would be remiss not to mention the field's pioneer, Andreas Kappeler, even if he does not teach in the US], all of which devote considerable attention to the eighteenth century. There are also quite a few volumes about empire in general, almost all of which feature Russia prominently. Finally, there are several recent monographs, journal articles, and collectively authored volumes.

What is distinctive about empire studies as a subgenre, vis-à-vis, for example, histories of the Russian state? In addition to the issue of periodization discussed previously, much of this literature inquires into what an imperial perspective looks like and how it might affect our understanding of center and periphery. More concretely, does the recognition of the profoundly multi-peopled essence of empire, combined with the relatively small number of formal, well-staffed state institutions outside of the metropoles vis-à-vis other states force us to move away from a Moscow/St. Petersburg-centric view of Russia? Another key question involves center-periphery relations, specifically whether, and to what extent, the Empire was rigidly controlled by the center.

In a very recent and already acclaimed study, John LeDonne (LeDonne, 2020) has argued insistently in the affirmative. Somewhat reminiscent of Marc Raeff's foundational concept of "the well-ordered police state" (Raeff, 1975), LeDonne looks at the empire holistically, from the perspective of the state. Raeff, let us recall, saw this well-ordering as embedded fundamentally in the law, a way of making an otherwise disorderly empire 
comprehensible to its overseers in St. Petersburg and their agents in the guberniias, and thereby render it governable. LeDonne, however, goes much further than Raeff. Much like Jacob Soll's characterization of JeanBaptiste Colbert, and more generally of the reign of Louis XIV in France, (Soll, 2009), he defines the empire itself as a 'unitary state', one in which the autocracy insistently pursued a mode of dominance characterized by a uniformity imposed from above, and by centralization and standardization throughout nearly the entire realm, all in pursuit of a "fortress empire." Several other current scholars concur. Building upon his earlier writings on the peoples of the eastern steppe, Michael Khodarkovsky depicts Russian authorities as adopting what might be termed a command approach in their relations with distant inorodtsy and inovertsy, from the conquest of Kazan through nearly all the Imperial period. Formal borders, he emphasizes, were for all practical purposes nonexistent on the eastern steppe, enabling populations to move around within a broad terrain across multiple empires. Nevertheless, within Russian space power flowed from the center, with relatively little room for a negotiated "middle ground" or local agency. (Khodarkovsky, 2002).

But on this point, there is considerable disagreement. To some extent the question of interpretation hinges on geography: if one starts far from the capital, the Empire tends to look somewhat different than it does if the analysis radiates out from the metropole. For several contemporary scholars the Empire's sheer size, immense ethnic and linguistic diversity, low population density and what Stephen Hoch once termed "chronic under government" rendered this mode of uniformity impossible on the ground. To truly understand the state's relations with its many millions of non-Russians, they argue, we must refocus, away from central institutions and mandates as our ground zero, and instead towards local populations and regional centers of authority. Thus, Brian Boeck's 2009 study poses the issue from the perspective of the Don Cossack host, and in his account the interaction between sech' and crown was more dynamic, even though, of course, the Russian authorities were forever looking for ways to domesticate the region in the interests of the state. Serhii Plokhy has produced an immense body of scholarship on Ukraine, the Hetmanate, the Ruthenian Metropolia, the emergence of Slavic 'nations', and the place of the lands and peoples from the Dniepr/Dnepro to the Carpathians within the Russian Empire. For obvious reasons these tend to give considerable attention to the eighteenth century. Like Boeck, his Russian Empire is fundamentally multi-peopled, a complex and contentious reality that 
is defining throughout a century during which the Hetmanate existed, disappeared, and then reappeared.

A similar dynamic emerges in Ian Campbell's monograph on Kazaks and the Imperial Russian state, the first chapter of which is devoted largely to the eighteenth century (Campbell, 2017). Willard Sutherland's analysis of Steppe colonization takes the argument a step further. His work brings an environmental and economic perspective ("taming the wild field") to the study of the steppes, and in particular the relations between empire and steppe peoples over the eighteenth and nineteenth centuries. (Sutherland, 2004) In the process he subtly problematizes our understanding of the imperial project by suggesting that in some instances these relations were distinctly "unimperial." Matthew Romaniello's comparison of eighteenthcentury Britain and Russia has taken empire in a different direction still. (Romaniello, 2019) Romaniello is acutely interested in borderlands and their populations, but relationships between state and subjects is rather less central to his topic than is economic interaction within and across those borders, as sites of competition for non-European markets. His account looks at economic competition rather than war and diplomacy as a defining feature of the imperial project in that region, a very welcome alternative to that tired old war horse, 'the Eastern Question.' He examines the movement of commodities during the eighteenth century across the length and breadth of the Eurasian space, a great deal of which traversed Russia, and in this way situates Russia squarely in the middle of multicontinental commerce.

More recently the hi-tech field of historical mapping ("the new spatial history") has introduced geospatial technologies to the study of empire. Prominent among these are Kelly O'Neill's work on Crimea and her digital sites, "The Imperiia Project" and "Beautiful Spaces" (O'Neill, 2010, 2017, 2018), along with John Randolph, who has employed similar methodologies in his ongoing study of coachmen (ямщики), and in a multiperson laboratory in digital humanities. These technologies provide an optical and physical concreteness, sometimes utterly breathtaking as we see them from space, to our understanding of some of the fundamental features through which empires/states functioned, including highways from the distant past, migration patterns, shifting waterways, abandoned settlements, and the like.

At the end of the day, though, the allure of the center, the capital St. Petersburg in all its symbolism and power, never seems to fade, even as some scholars seek to decenter them. Richard Wortman's magisterial 
two-volume Scenarios of Power: (Wortman, 1995) slightly predates the twenty-first century, but its impact on eighteenth-century studies has been enormous. The scholarship that has ensued covers a disparate set of themes that often draw upon one another, but to date they have not quite coalesced into an agreed-upon set of core questions or points of disputation. Relatively recent examples of representations-inflected scholarship include monographs by Ernest Zitser on what he terms "sacred parody" at Peter's court (e.g., The All-Drunken Synod) (Zitser, 2004); Susan McCaffery on the symbolic place of the Winter Palace for the population of St. Petersburg (McCaffery, 2018); and Vera Proskurina on poetic representations of the court in the reign of Catherine II (Proskurina, 2011). Other studies, such as Robert E. Jones on the St. Petersburg grain trade (Jones, 2013) and George Munro on urban design and the physical evolution of the city (Munro, 2008) are less concerned with the cultural and representational issues that have become interwoven within ongoing conversations taking place throughout the field.

\section{LIVED EXPERIENCES, STRUCTURES AND CATEGORIES OF EVERYDAY LIFE}

There remains an ongoing interest in the relationship between the formal structures of Russian society and lived experiences (interiorities), especially of people outside the elites, as reflected in archival records, diaries, and letters. One outstanding example of this is David Ransel's study of the life and self-reflections of the provincial merchant Ivan Tolchenov (Ransel, 2009) through the lens of Tolchenov's extensive diary, a rare and precious source for a provincial of his estate in this period. Related to this is Alexander Martin's annotated translation of the memoir of a village priest, Dmitrii Rostislavov (A. Martin, 2004), still quite rare in the eighteenth century. Rostislavov's memoir is quite different from Tolchenov's in tone and focus, more polemical, judgmental, and quite bitter. But like Ransel, Martin provides a detailed and intimate portrait both of the subject himself as well as the ego-text he produced. Daniel Waugh's volume (written in Russian) on the self-appointed early eighteenth-century Viatka town chronicler, Semen Fedorovich Popov and his compilation, "Anatol'evskii sbornik" (Waugh, 2003) provides yet another micro-study to this literature. Waugh's primary interest here is in the way in which Popov composed and assembled his miscellany, but this exercise in archaeography also involves 
a serious reconstruction of the life and thinking of this heretofore virtually unknown figure.

Working on a broader scale, Alison Smith (A. Smith, 2014, 2017, 2019, 2020) has reprised the familiar-yet-enigmatic question of social estates (сословия) that historians have long pondered, but in her case with a somewhat different set of questions. Historians including Gregory Freeze (Freeze, 1986), Elise Wirtschafter (Wirtschafter, 1994, 1997), and Michael Confino (Confino, 2008) have tended to emphasize the legal and formal parameters of estate categories, including what they commanded and forbade, or, as in Freeze's work, whether the idea of 'estates' penetrated into everyday usage vis-à-vis older terms such as 'rank' ('чин'), or alternatives such as 'standing' ('состояние'). Smith's work inquires instead into the concrete meaning of these categories for lived experiences ofmostly-common people (excluding, of course, unfree peasants), up to and including wealthy merchants during the eighteenth and early nineteenth centuries. This is also the focus of a fair volume of research in Russia, France, the UK, and Germany, which, while still in its early days, seems to be converging around a somewhat more fluid picture of social structure than legal terms had conveyed. Occupations, social milieux, and networks could, it appears, move more easily than we had thought beyond the implicit confines of one's estate. Previous historians, this work seems to imply, have hypostasized 'estate' a bit too much.

Although not explicitly focused on estate, Alexander Martin's monograph on the evolution of Moscow from the time of Catherine II through Emancipation (A. Martin, 2013) combines an exploration of the human landscape with the physical evolution (growth, destruction, and reconstruction) of the city. Although slightly beyond our time period, the section on the Napoleonic occupation is especially informative. Colum Leckey's book on the Free Economic Society (Leckey, 2011) also fits into this category. These two works share the current preference for quotidian and "real life" narratives over large, sweeping categories. One would not characterize them as micro-histories exactly, but they do endeavor to recount how individuals and groups experienced change, war, suffering, the frisson of camaraderie, and reform at the time. 


\section{GENDER}

The study and conceptualization of gender has continued to grow broader and more complex in the past two decades, albeit rather more slowly in Russian eighteenth-century studies than in some other national histories, or for other time periods of Russian history. In our area it has by and large concentrated on women's history-life histories, roles both enforced and transcended, performativity, representations, and experiences.

In light of the prominence of female rule in Russia between 1725 and 1796 it is not surprising that royal women and those of the upper nobility have been in the forefront. Catherine II, as ever, commands attention, some of which was discussed in the earlier section on rulership. Curiously, though, there have not been any full-length scholarly biographies for some time (at least not by US academics; several have appeared elsewhere in recent years, and of course there is never a shortage of new popular biographies). Mark Cruse and Hilde Hoogenboom's extensively annotated retranslation of Catherine's memoir, including a very detailed preface that provides a critical comparison of the revisions she made over time, has been a valuable contribution (Cruse and Hoogenboom, 2005, pp. ix-lxix) in allowing us to trace what Catherine sought as her personal legacy and posthumous reputation as she wrote and rewrote the story of her first decades in Russia. As to her many years on the throne, Douglas Smith has published a translation-cum-commentary of much of the CatherinePotemkin personal correspondence from the 1770 s and 1780 s (D. Smith, 2004). The intermingling of personal intimacy, mutual adoration, and raison d'état that characterizes this cache of letters is a further glimpse into the Empress' inner life and thinking. A recent dissertation by Kelsey Rubin-Detlev has examined the broad sweep of Catherine's extensive correspondence with philosophes as well as with prominent Russians, largely from the perspective of understanding how she deployed Enlightenment discourse and rhetoric. (Rubin-Detlev, 2015).

By comparison, other female rulers have attracted limited attention, at least from an explicitly gendered perspective. Two exceptions are Catherine I, seen largely through the lens of the veneration of Saint Catherine, (Marker 2007) and Elizabeth (the ongoing project of Catherine Evtuhov). A related work is Russell Martin's just-published close study of multiple generations of royal weddings and the complex and often cut- 
throat politics of bride selection. Most of his attention is concentrated on sixteenth and seventeenth-century Muscovy, but the chronological span extends into the mid-eighteenth century (1500-1745) (R. Martin, 2021).

Away from the throne, the activities of noblewomen within household, estate, and in some cases (e.g., Ekaterina Dashkova) service to the state (Academy of Sciences and the Russian Academy). Much of this literature has been biographical, often based on memoirs or correspondence. (e.g., Michelle Marrese's articles on Dashkova and other elite women (Marrese, 2010, 2015, 2016); my own work on Anna Labzina, (Marker 2000, 2001), and several others. One exception is Douglas Smith's biography, The Pearl, of Praskovia Kovaleva, the serf diva owned by Nikolai Sheremetev (D. Smith, 2008), who while remaining in bondage, lived her life largely within the milieu of elites.

In an earlier work on noble estates, Michelle Marrese (Marrese, 2002) took engendering in quite a new and important social direction through an explication of the surprisingly robust activities of noblewomen in managing estates and buying and selling property. This focus on household and property extends also to Daniel Kaiser's work on wills and inheritance (Kaiser 2006). Anna Kuxhausen's study of the image of childhood in Russian letters (Kuxhausen, 2013) places tropes of masculinity and femininity at the forefront. Kuxhausen's remains one of very few works to date to explore eighteenth-century Russian masculinities, a topic whose potential source base seems rich and open to analysis for future scholars.

\section{IN LIEU OF A CONCLUSION}

As I have tried to show, recent scholarship on the eighteenth century has crossed over multiple formerly unbreachable boundaries and has subjected others to systematic interrogation. If anything, it is more empirical and microscopic and less paradigmatic than before, almost militantly so. The old "big questions, big paradigms" approach, that for so long guided our work is in full retreat. For the most part this has been intellectually invigorating, freeing individual scholars to question anything and everything, and to bring to bear whatever methodologies and analytical lenses they deem useful. But here let me gently suggest that the big questions (or at least some of them) also have a rightful place in our narratives, not as essentialisms or teleologies to be sure, but simply as questions worthy of reflection. Perhaps one productive "turn" in our 
field might juxtapose the research vibrancy we are witnessing today with the deeply reflective ruminations with which big ideas have in the past enriched our work. Time will tell.

\section{Bibliography}

BeCker, Seymour, "Russia and the Concept of Empire," Ab Imperio, no. 3-4 (2000): 32942. https://doi.org/10.1353/imp.2000.0032

BOECK, BRIAN, Imperial Boundaries: Cossack Communities and Empire Building in the Age of Peter the Great (Cambridge, 2009). https://doi.org/10.1017/CBO9780511642104 CAMPBELL, IAN, Knowledge and the Ends of Empire: Kazak Intermediaries \& Russian Rule on the Steppe, 1731-1917 (Cornell, 2017). https://doi.org/10.7591/9781501707902

CHRISSIDIS, NikolaOs, An Academy at the Court of the Tsars: Greek Scholars and Jesuit Education in Early Modern Russia (NIU, 2016).

COLLIS, ROBERT, The Petrine Instauration: Religion, Esotericism, and Science at the Court of Peter the Great, 1689-1725 (Brill, 2011). https://doi.org/10.1163/9789004224391

Confino, Michael, “The 'Soslovie' (Estate) Paradigm: Reflections on Some Open Questions," Cahiers du Monde russe 49, no. 4 (2008): 681-699. https://doi.org/10.4000/ monderusse. 6900

CRACRAFT, JAMES, The Petrine Revolution in Russian Architecture (Chicago, 1988).

- The Petrine Revolution in Russian Imagery (Chicago, 1994).

- The Petrine Revolution in Russian Culture (Harvard, 2004).

- The Revolution of Peter the Great (Harvard, 2003).

CREWS, RoBert, For Prophet and Tsar: Islam and Empire in Russia and Central Asia (Harvard, 2006).

FrEEZE, GREgory, The Russian Levites: Parish Clergy in the Eighteenth Century (Harvard, 1980).

- "The Soslovie (Estate) Paradigm and Russian Social History," American Historical Review Vol. 96, no. 1 (1986): 11-36. https://doi.org/10.2307/1867233

HAMBURG, GARY, Russia's Path Towards Enlightenment: Faith, Politics, and Reason, 15001801. Yale, 2016. https://doi.org/10.12987/yale/9780300113136.001.0001

Hoogenboom, HILDE, "The Community of Letters and the Nation State: Bio-Bibliographic Compilations as a Transnational Genre Around 1700," in Women Telling Nations Amelia Sanz et al., eds. (Brill, 2014), 271-292. https://doi.org/10.1163/9789401211123_016

- and MARK CRUISE (trans. and eds.), Memoirs of Catherine the Great (Random House, 2005).

IVANOV, ANDREY V., A Spiritual Revolution: The Impact of Reformation and Enlightenment in Orthodox Russia (Wisconsin, 2020). https://doi.org/10.2307/j.ctv17hmb4d

JONES, ROBERT E., Bread Upon the Water: The St. Petersburg Grain Trade and the Russian Economy, 1703-1811 (Pittsburgh, 2013). https://doi.org/10.2307/j.ctt1b7x65j

KAISER, DANIEL, "Gender, Property, and Testamentary Behavior: Eighteenth-Century Moscow Wills", Harvard Ukrainian Studies 28, no. 1/4 (2006): 511-520.

Khalid, AdeEB, Central Asia: A New History from the Imperial Conquests to the Present (Princeton, 2021). https://doi.org/10.1515/9780691220437 
KHOdARKOVSKY, MichaEL, Russia's Steppe Frontier: The Making of a Colonial Empire, 1500-1800 (Indiana, 2002).

Kivelson Valerie and Neuberger, JoAn, Picturing Russia: Explorations in Visual Culture (Yale, 2008). [The material on the eighteenth century is in sections 10-15]. https://doi. org/10.2307/j.ctt5vm1n6

KIVELSON, VALERIE and SUny, RonALd GRIgor, Russia's Empires (Oxford, 2016).

KIZENKo, NADIESZDA, Good for the Souls?: Church, State, and Russian Society at Confession. Oxford, 2021. https://doi.org/10.1093/oso/9780192896797.001.0001

- "The Sacrament of Confession as Encounter with Early Modernity," in Paul Bushkovitch, ed., The State in Early Modern Russia: New Directions (Slavica, 2019), 163-190.

Kollmann, Nancy ShieldS, The Russian Empire, 1450-1801 (Oxford, 2016). https://doi. org/10.1093/acprof:oso/9780199280513.001.0001

KUXHAUSEN, ANNA, From the Womb to the Body Politic: Raising the Nation in Enlightenment Russia (Wisconsin, 2013).

LECKEY, COLUM, Patrons of Enlightenment: The Free Economic Society in EighteenthCentury Russia (Delaware, 2011). https://doi.org/10.1057/9781137265258_10

LEDONNE, John, Forging a Unitary State: Management of the Eurasian Space, 1650-1850 (Toronto, 2020). https://doi.org/10.3138/9781487533311

LEVITT, MARCUS, The Visual Dominant in Eighteenth-Century Russia (NIU, 2011). https:// doi.org/10.1515/9781501757983

MARKER, GARY and MAY, RACHEL, Days of A Russian Noblewoman: The Memories of Anna Labzina (NIU Press, 2001).

- Imperial Saint: The Cult of Saint Catherine and the Dawn of Female Rule in Russia (NIU, 2007).

- “Love One's Enemies: Ioasaf's Krokovs'kyi's Advice to Peter in 1702," Harvard Ukrainian Studies 29 (2007): 193-224.

- "The Enlightenment of Anna Labzina: Gender, Faith, and Public Life in Catherinian Russia" Slavic Review 59, no. 2 (2000): 369-90. https://doi.org/10.2307/2697057

MARRESE, Michelle LAmARCHe, A Woman's Kingdom: Noblewomen and the Control of Property in Russia 1700-1861 (Cornell, 2002). https://doi.org/10.7591/9781501728518

- "Performing Womanhood in Eighteenth-Century Russia: Cultural Identity in the Letters of Ekaterina Rumiantseva and Dar'ia Saltykova, in Schonle, et al. Europeanized Elite (2016), 90-110.

- "The Poetics of Everyday Behavior Revisited: Lotman, Gender, and the Evolution of Noble Identity", Kritika 11, vol. 4 (2010): 701-740. https://doi.org/10.1353/kri.2010.0004 "Princess Dashkova and the Politics of Language in Eighteenth-Century Russia," in Rzheoutki et al. eds., French and Russian in Imperial Russia (2015), 31-47.

MARTIN, AleXAnder, Enlightened Metropolis: Constructing Imperial Moscow: 1762-1855 (Oxford, 2013). https://doi.org/10.1093/acprof:oso/9780199605781.001.0001

- (trans. and ed.), Provincial Russia in the Age of Enlightenment: The Memoir of a Village Priest, Dmitrii Ivanovich Rostislavov (NIU, 2004).

MARTIN, RUSSELL, The Tsar's HappyOccasion:Ritualand Dynastyinthe WeddingsofRussia's Rulers, 1500-1745 (NIU, 2021). https://doi.org/10.7591/cornell/9781501754845.001.0001 MCCAFFERY, SUSAN, The Winter Palace and The People (NIU, 2018). https://doi.org/10. $1515 / 9781501758003$ 
Moon, David, The Plough that Broke the Steppes: Agriculture and Environment on Russia's Grasslands, 1700-1914 (Oxford, 2013). https://doi.org/10.1093/acprof:oso /9780199556434.001.0001

Munro, George, The Most Intentional City: St. Petersburg in the Reign of Catherine the Great (Fairleigh Dickinson, 2008).

OKENFUSS, MAX, The Rise and Fall of Latin Humanism in Early Modern Russia: Pagan Authors, Ukrainians, and the Resiliency of Muscovy (Brill, 1995). https://doi.org/10. $1163 / 9789004247185$

"The Jesuit Origin of Petrine Education," The Eighteenth Century in Russia. John G. Garrard ed., (Oxford, 1973), 106-130.

O'NeILL, Kelly, Claiming Crimea: A History of Catherine the Great's Southern Empire (Yale University Press, 2017). https://doi.org/10.12987/yale/9780300218299.001.0001

- "The Imperia Project. Canvas History: A Spatial History of the Russian Empire." Imperia.scalar.fas.harvard.edu. 2017.

- "Beautiful Spaces: an exercise in narrative mapping \& Crimean history." beautifulspaces.omeka.fas.harvard.edu. 2018.

- "Rethinking Elite Integration: Crimean Murzas and the Evolution of Russian Nobility," Cahiers du monde russe 51, no. 2-3 (2010): 397-417. https://doi.org/10.4000/ monderusse.9195

OStRowSKI, DonALD, "The End of Muscovy: The Case for Circa 1800," Slavic Review 69, no. 2, (2010): 426-438. https://doi.org/10.1017/S0037677900015072

- The Imperiia Project: Spatial Histories of the Russian Empire http://scalar.usc.edu/ works/imperiia/index

Petrovsky-Shtern, Yohanan, The Golden Age of the Shtetl (Princeton, 2014). https://doi. org/10.2307/j.ctt6wpz15

Proskurina, Vera, Creating the Empress: Politics and Poetry in the Age of Catherine II (Academic Studies Press, 2011). https://doi.org/10.2307/j.ctt1zxsj03

RAEFF, MARC, The Well-Ordered Police State: Social and Institutional Change Through Law in Russia and the Germanies, 1600-1800 (Yale, 1975).

RANDOLPH, John, "The Singing Coachman or The Road and Russia's Ethnographic Invention in Early Modern Times," Journal of Modern History 11, no. 1-2 (2007): 33-61. https://doi.org/10.1163/157006507780385044

- "Between Friends, the Coachman: Enlightenment Encounters Empire in Russia's Eighteenth Century" The Europeanized Elite in Russia, 1762-1825. Andreas Schönle, Andrei Zorin and Alexei Evstratov eds. (Cornell, 2016), 261-276. https://doi.org/10. 1515/9781501757723-017

- "Russian Route: the Politics of the Petersburg-Moscow Road, 1700-1800," in Mark Bassin, Christopher Ely, and Melissa K. Stockdale, eds., Space, Place, and Power in Modern Russia: Essays in the New Spatial History (NIU, 2010), 81-99.

RANSEL, DAVID L., A Russian Merchant's Life: The Life and Adventures of Ivan Alekseevich Tolchenov, Based on His Diary (Indiana, 2009).

RIEBER, ALFRED, The Struggle for the Eurasian Borderlands: From the Rise of Early-Modern Empires to the End of the First World War (Cambridge, 2014). https://doi.org/10.1017/ CBO9781107337794

Romaniello, MAtTHEW, Enterprising Empires: Russia and Britain in Eighteenth-Century Eurasia (Cambridge, 2019). https://doi.org/10.1017/9781108628600 
Rubin-DetLeV, Kelsey, "The Letters of Catherine the Great and the Rhetoric of Enlightenment," PhD dissertation, (U. of Oxford, 2015).

SKINNER, BARBARA, The Western Front of the Eastern Church: Uniate and Orthodox Conflicts in $18^{\text {th }}$-Century Poland, Ukraine, Belarus, and Russia (NIU, 2009).

SMITH, ALISON, "Honored Citizens and the Creation of a Middle Class in Imperial Russia," Slavic Review 76, no. 2 (2017): 327-49. https://doi.org/10.1017/slr.2017.81

- For the Common Good and Their Own Well-Being: Social Estates in Imperial Russia (Oxford, 2014).

- "False Passports, Undocumented Workers, and Public (Dis)Order in Late EighteenthCentury Russia," Journal of Social History (Spring, 2020): 1-21.

- New Town, New Townspeople: Transforming Gatchina in the 1790s," Vivliofika: E-Journal of Eighteenth-Century Russian Studies 7 (2019): 86-101. https://doi.org/10.21900/j. vivliofika.v7.537

SMITH, DOUGLAS, The Pearl: A Tale of Forbidden Love in Catherine the Great's Russia (Yale, 2008).

SMITH-PETERS, Susan, “Making Empty Provinces: Eighteenth-Century Enlightenment Regionalism in Russian Provincial Journals." REGION: Regional Studies of Russia, Eastern Europe, and Central Asia 4, no. 1 (Winter 2015): 7-29. https://doi.org/10.1353/ reg.2015.0003

SOLL, JACOB, The Information Master: Jean Baptiste Colbert's State Information System (Michigan, 2009). https://doi.org/10.3998/mpub.243021

SUTHERLAND, WILLARD, Taming the Wild Field: Colonization and Empire on the Russian Steppe (Cornell, 2004).

TSAPINA, OlgA, "Secularization and Opposition in the Time of Catherine the Great," Dale Van Kley and James E. Bailey eds. Religion and Politics in Enlightenment Europe, (Notre Dame, 2001), 355-392.

- "Beyond the Synodal Church: Problems and Perspectives in the Study of $18^{\text {th }}$-Century Russian Orthodoxy," Classical Russia, 1 (2006): 13-45.

- «'Смеха достойное позорище'? Дискуссия о веротерпимости и образ старообрядца в России эпохи Просвещения,» В. Е. Борисов ред., О вере и суевериях. Сборник статей в честь Е. Б. Смилянской. М. (Индрик, 2014), 207-256.

- "Was There a Russian Tradition of Church-State Relations?" The State in Early Modern Russia: New Directions. Paul Bushkovitch, ed. (Slavica, 2018), 1-26.

- Vivliofika: An E-Journal of Eighteenth-Century Russian Studies. Special issue: "Protestantism in Russia During the Eighteenth and Early Nineteenth Centuries." Ingrid Schierle ed. (2017).

WaUgh, DANIEL, История одной книги: Вятка и «не-современность в русской культуры Петровского времени. (The History of a Book: Viatka and "Non-Modernity" in Russian Culture of the Petrine Era (St. Petersburg, 2003).

WERTH, PAUL W., The Tsar's Foreign Faiths: Toleration and the Fate of Religious Freedom in Imperial Russia (Oxford, 2014). https://doi.org/10.1093/acprof:oso/9780199591770. 001.0001

WhITTAKer, CYNTHIA H., Russian Monarchy: Eighteenth-Century Rulers and Writers in Political Dialogue (NIU, 2003).

WIRTSCHAFTER, ELISE KIMERLING, Religion and Enlightenment in Catherinian Russia: The Teachings of Metropolitan Platon (NIU, 2013). https://doi.org/10.1515/9781501757464 
- Social Identity in Imperial Russia (NIU, 1997).

- Structures of Society: Imperial Russia's “Peoples of Various Ranks" (NIU, 1994).

- The Play of Ideas in Russian Enlightenment Theater (NIU 2003).

WORTMAN, RICHARD, Scenarios of Power: Myth and Ceremony in Russian Monarchy (Princeton, 1995).

ZITSER, ERNEST, The Transfigured Kingdom: Sacred Parody and Charismatic Authority at the Court of Peter the Great (Cornell, 2004.)

ZITSER, ERNEST, "The Difference that Peter Made" The Oxford Handbook of Modern Russian History. Simon Dixon ed. (2016). https://doi.org/10.1093/oxfordhb/9780199236701.013. 008

- "Post-Soviet Peter: New Histories of the Late Muscovite and Early Imperial Russian Court," Kritika: Explorations in Russian and Eurasian History 6, no. 2 (2005): 375-392. https://doi.org/10.1353/kri.2005.0032

- "The Vita of Prince Boris Ivanovich 'Korybut'-Kurakin: Personal Life-Writing and Aristocratic Self-Fashioning at the Court of Peter the Great," Jahrbücher für Geschichte Osteuropas 59, no. 2 (2011): 163-194.

- and Robert Collis, "On the Cusp: Astrology, Politics, and Life-Writing in Early Imperial Russia," American Historical Review 120, no. 4 (2015): 1618-1652. https://doi.org/10.1093/ $\mathrm{ahr} / 120.5 .1619$ 